\title{
REASONS FOR GOVERNMENT INACTION AND ITS NEGATIVE CONSEQUENCES: TWO CASE STUDIES OF FAILED WATER MANAGEMENT INITIATIVES IN ALBERTA, CANADA
}

\author{
LORRAINE A. NICOL \& CHRISTOPHER J. NICOL \\ Department of Economics, University of Lethbridge, Canada
}

\begin{abstract}
In the province of Alberta, Canada, exploring new strategies to improve water management has become necessary. One such strategy involved improvements to the water transfer system and a second involved the creation of a water sharing strategy within a regional partnership. Despite the prospect of improving water management, proposed advancements to the water transfer system were not implemented, and the regional partnership floundered when it bifurcated along urban and rural lines. This study focused on these two failed attempts to improve water management as case studies, highlighting a possible role the provincial government could have played in enhancing water management. The first case study found that the politically-imbued nature of water management presented the greatest impediment to government implementing changes to the water transfer system. The second case study uncovered a host of measures the government could have undertaken to provide leadership and support but failed to do so. In both instances, important opportunities to improve water management failed, in part due to the politicization of water on the one hand, and government's unwillingness to provide leadership and support on the other.
\end{abstract}

Keywords: water management, Alberta, water transfers, regional partnerships, watershed.

\section{INTRODUCTION}

Water is a commodity that has become increasingly challenging to manage over time. Factors common to this challenge across countries and jurisdictions include: (a) the extreme diversity of water uses across different types of users; (b) institutions that are acceptable and workable in situations of abundance but which can quickly become dysfunctional in times of scarcity; (c) multiple institution involvement in water management and concomitant inconsistency of across-institution goals; and (d) institutions that privilege certain types of uses and users over others [1]. Under these circumstances it has become broadly recognized that new water management principles and instruments are necessary [2].

In Alberta, new water management principles and instruments have included shifts from: (a) process to outcomes; (b) water management to watershed management; (c) regulation of water management to shared, cooperative water management responsibility; and (d) topdown government making authority to shared decision-making among multiple stakeholders [3]. The embodiment of these changes in emphases was expressed in the province's Water for Life Strategy of 2003 which had as its primary objectives: safe and secure drinking water, healthy aquatic ecosystems and reliable quality water supplies for a sustainable economy. Potential mechanisms used to achieve those objectives included economic instruments; watershed management plans; and water conservation and productivity plans for major sectors such as industries, municipalities and irrigation districts [4]. For southern Alberta, where water demands have been particularly acute, contemplating new water management strategies has become necessary. 
Our goal in this study is to investigate the obstacles to government action and expectations of government support based on two case studies that represent new water management strategies. A description of Alberta's water management and regional framework is provided in the background Section 2. The two case studies' methods and results are presented in Section 3. The studies' conclusions are summarized and discussed in Section 4.

\section{BACKGROUND}

The demands for water in Alberta have been intense given the province's economic and population growth. In the past 20 years, the average annual GDP growth rate was 3.6 percent. Between 2004 and 2014 Alberta's population increased by 27 percent, the highest increase of any province or state in North America [5]. Given that much of population and economic growth has occurred in the southern half of the province, water demand has been particularly acute for the largest southern river basin, the South Saskatchewan River Basin (SSRB) and the four sub-basins within it - the Bow River, Oldman, Red Deer and South Saskatchewan. This area is depicted in the map below.

By 2005, warning signs of significant environmental distress of river reaches within the SSRB began to appear. A provincial government study that year found 30 out of 33 river reaches had suffered some degree of environmental impact, 22 main stem river reaches were moderately impacted, five heavily impacted, and three degraded [6]. In response to these warning signs the provincial government took the unprecedented step of no longer accepting applications for new licensed water allocations for the Bow, Oldman and South Saskatchewan River sub-basins. Consequently, the extraction of water for consumptive use had become fixed within nearly every river system in southern Alberta.

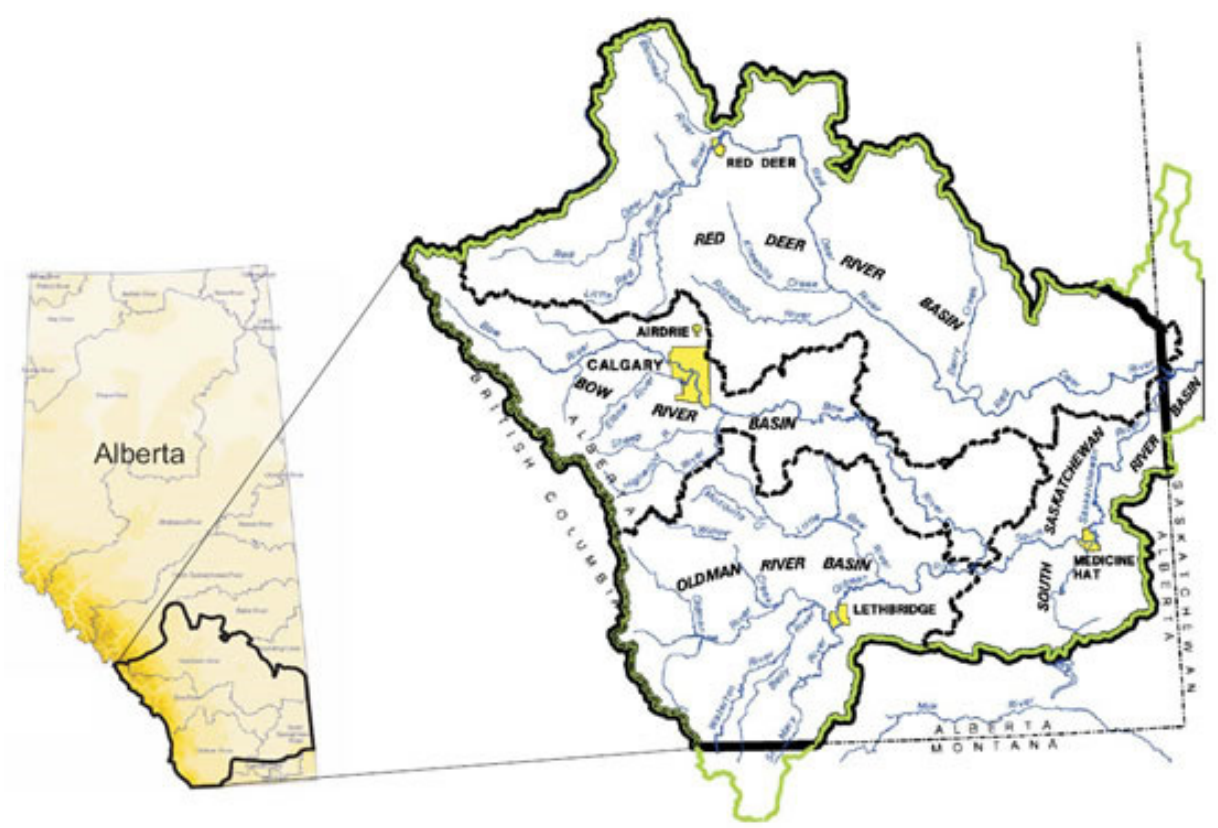

Figure 1: South Saskatchewan River Basin. (Source: http://aep.alberta.ca/water/ programs-and-services/south-saskatchewan-river-basin-water-information/ default.aspx.) 
Given the moratorium on new licensed water allocations, the province required mechanisms to reallocate water within those basins. One such mechanism, facilitated through Alberta's Water Act, was the transfer of an allocation of water under a licence. This can include all or part of an allocation of water from a license, either permanently or for a specified period. In August 2006 when the provincial environment ministry released the Approved Water Management Plan for the SSRB, the foundation for the first water market in Canada was established. This initiative is pertinent to the first section of this study.

As the water market began to slowly take shape in Alberta, criticisms over the significant time and transaction costs involved in the process began to emerge [7]. In addition, the prior-appropriation system on which the province's water allocation system is based was seen by some as antiquated, outmoded, and unable to provide the flexibility needed to deal with the competing demands for water [8], [9]. Therefore, in 2008 three studies, commissioned either by a government department or government-funded organization, were initiated relating to water allocation, water transfers and water management. The three studies were: The Environment Minister's Advisory Group on Water Management and Allocation (MAG), the Water Allocation Transfer System Upgrade Project (WATSUP) team, and a study undertaken by the Alberta Water Research Institute (AWRI). The studies took 18 months to complete. Findings and recommendations from all three studies were released on the same day in November 2009.

Ultimately none of the reports recommended changing the water allocation framework as the government deemed the current systems meets Alberta's needs. However, numerous other recommendations from the three reports ranged from establishing water for conservation purposes, to assigning unused water, to improving the application and approval process of the water transfer system (for a detailed account see [10]). The WATSUP report focused on the water transfer system. It established 23 recommendations which included, for example, creating a three-tier application process whereby the degree of scrutiny employed on the part of the Director in the approval process would range from none to full discretion. To date, none of the recommendations in the three reports have been implemented. The reasons for lack of implementation are explored in the first case study presented in this paper.

An additional new water management initiative attempted around the same time, pertinent to the second case study, was the creation of the Land Use Framework (LUF) in 2008. It established the requirement for the development of regional plans to manage land and water. Prior to 2008 (and the LUF), land and water resource management in Alberta evolved separately. The development of the provincial government's LUF and its legislative outcome, the Alberta Land Stewardship Act (ALSA) of 2009, created seven regions based on the major watersheds in Alberta under which regional plans for each watershed were to be developed. Central to the legislation is the notion of cumulative effects management that sets regional thresholds for air and water. No similar land-use framework existed anywhere else in Canada, or in any other jurisdiction in the Englishspeaking world [11].

The development of the LUF and ALSA in Alberta are consistent with contemporary thinking that land and water management require larger spatial scales, and many more stakeholders than previous envisioned [12]. It is contended that the territorial space through which the environment is best regulated is the city-region [13]. But studies of regionalism point to the highly complex and difficult nature of establishing regional alliances because of the multiplicity of actors and networks involved. Within these initiatives there is a need for government to provide a supportive framework [14]. Measures taken will be partial, limited 
and possibly counterproductive if not located within a broader, supportive structure [15][17].

Under the LUF, the city of Calgary was mandated to create a metropolitan plan that would guide development and focus on sustainable principles for the region [18]. A few years earlier, in 2005, 18 municipalities had already come together under the Calgary Regional Partnership (CRP). The municipalities included the city of Calgary, 13 smaller cities and towns, and four rural municipalities, all of which together account for approximately 1.1 million people, and a significant percentage of the land in the region. Except for the town of Nanton, all municipalities are situated within the Bow River subbasin. A map of the region is provided below.

Unfortunately, when they could do so (prior to the closure of the Bow River Basin to applications for new licenses in 2005) many municipalities in the Calgary region did not apply for water license that would be sufficient to accommodate their long-term growth [19]. Hence, a study commissioned by the CRP in 2007 found the three rural municipalities of Rocky View County, Wheatland County and the municipal district of Foothills, did not have sufficient water licenses for large-scale regional growth. This CRP study also determined that, for nine additional municipalities, their current water supplies would no longer be sufficient within five to 20 years [20]. Calgary, however, had enough water license allocation for three times its population and within the CRP was willing to create and operate a water utility to share water with member municipalities that needed water. Accessing water was therefore a motivating factor for some municipalities to participate in the CRP [21].



Figure 2: CRP Area. (Source: https://www.uleth.ca/dspace/handle/10133/3494.) 
By 2008 the CRP had created a 60-year plan for the region, referred to as the Calgary Metropolitan Plan (CMP). Under the CMP, water access and services would be provided to new concentrated residential areas of eight to ten housing units per acre. These areas were called 'compact urban nodes'. Land for the compact urban nodes was identified and would be set aside to accommodate the long-term population growth that was forecasted for the region. However, there emerged irresolvable issues over the exact placement and density of these nodes, as well as compensation to the owners of the land which the nodes would occupy. Also, the proposed voting framework of the partnership, whereby decisions would require a majority of the region's population and two-thirds of the CRP membership, became highly contested. For these reasons, in 2009 three of the four rural municipalities exited the partnership (the first rural municipality left in 2008, stating that the 'urban nature' of the partnership did not fit with its rural focus). This bifurcated the partnership along rural and urban lines. The expectation of provincial government leadership and support for the CRP in the years leading up the bifurcation of the partnership established the second line of inquiry of this study.

\section{CASE STUDIES: METHODS AND RESULTS}

\subsection{Improvements to the water transfer system}

The first case study in this paper focused on the reasons why recommendations from the MAG, WATSUP and AWRI reports were not implemented. The study focused on recommendations related to the water transfer system. Interviewees were recruited from the two of these three research studies which published the names of the individuals who authored the various reports. The two studies which identified their members were the MAG and WATSUP. In total 15 of the 26 people who authored the two studies agreed to be interviewed. They represented approximately half of the authors of each report, as well as a balanced representation from industry (three), government (four), non-government organizations (four), and academia (four), as reflected in the composition of the studies' teams. Interviews were conducted in a semi-structured telephone interview format between March 2014 and April 2014. Interviews were audio taped and transcribed, with results being coded according to themes.

In all cases, the interviewees indicated that the recommendations from their respective reports were favourably received by the then Minister of Environment. The results from the interviews revealed that the single most often cited reason for lack of implementation of the recommendations, especially as relates to the water transfer process, was that water had been in abundance in recent years so the need for or existence of water transfers would have been relatively uncommon and therefore 'off the radar'. Alberta has not had a drought since 2001 and in 2013 the province experienced the worst flood in its history. As one interviewee said, "the urgency (of improving the water transfer process) has slacked off". This reason was provided by eight of the 15 interviewees.

The second impediment most frequently cited was that water transfers had become too controversial politically. Environmental groups had become increasingly vocal opponents of water transfers. For example, one group railed against the water market in arguing that water serves social and environmental needs that are too important to be left to market forces [22]. The controversial nature of water transfers was cited by seven of the interviewees.

The third reason, cited by six interviewees, was that by the time the reports were delivered, government's attention had turned to other priorities, especially the unexpected 
and highly publicized controversy that had erupted over land-owner rights under the new regional land use framework.

The final reason cited for lack of implementation was frequent changes in the Minister of the Environment. New Ministers not only needed time to become familiar with their portfolio, they also came with their own set of priorities. Since 2009 when the reports were released, for example, there have been six different environment ministers as well as a change in government in 2015. This reason was given by five interviewees.

Perhaps not unexpectedly then, the interview findings reveal that improvements to the water transfer system were constrained by political realities. Based on this case study, at least one or more of the following factors would be necessary to implement improvements to Alberta's water transfer system: (a) a prolonged drought; (b) the ability to win support from environmental groups, (c) the absence of other more pressing priorities on the government's agenda; and (d) a Minister who is committed to change and remains in the portfolio for sufficient time to see the initiative to its conclusion. One interviewee stated "for government to act on something like this there needs to be some sort of crisis or emergency"5.

\subsection{The Calgary Regional Partnership}

The second case study sought to identify the expectations of the role of government in providing leadership and support for the CRP initiative. For this study, the opinions of those who were involved in the initiative were elicited. Three groups of individuals were identified as having various degrees of involvement in the CRP process leading up to its bifurcation, the 2005 to 2009 period. The first group comprised municipal elected representatives who had formal membership in the CRP process, given that they were members of the executive committee charged with developing the regional plan. This group included mayors, aldermen and reeves from the 18 municipalities. The second group were members of watershed organizations who did not sit on the executive committee but became members of working committees and were consulted through forums and workshops. The third group consisted of individuals from ancillary, water-related organizations. This third group involved individuals who did not sit on the executive committee nor were they necessarily consulted but they chose to be involved in the process through avenues open to the general public such as participation in workshops or other public forums.

In total, a cross-section of 28 individuals out of a potential 60 individuals were interviewed consisting of: (a) 16 municipal representatives; (b) seven people from watershed organizations; and (c) five people from ancillary organizations involved in water issues. This cross-section allowed for representation from all four rural municipalities, half the cities and towns involved in the CRP, half the watershed organizations in the Bow River sub-basin, and all the most prominent water-related organizations in the province. Interviews were conducted in person from May 2012 to September 2012 in an in-depth, semi-structured format. Interviews were audio taped and transcribed, with the results then being coded according to themes.

Virtually all interviewees spoke of the need for greater provincial leadership with respect to the CRP process specifically, as well as water management in general. As relates to the CRP process, one interviewee said it was the provincial government's responsibility to play a leadership role in the regional planning process rather than leaving it to municipalities to figure out ${ }^{3}$; another interviewee said if the province had legislation relating to transfer development credits and conservation easements it would have helped to 
prevent highly vocal criticism over the means of compensating the owners of the land designated as compact urban nodes ${ }^{4}$; three people believed the province could have acted quicker or could have done more to facilitate the rural municipalities' return to the CRP once they had left"; and finally, one informant said the province sent out "no shortage" of confusing signals about how the CRP would be folded into the broader LUF regional plan ${ }^{6}$.

As relates to water management, interviewees frequently noted that, generally speaking, the provincial government expended considerable time and energy at the strategic level of planning but were less inclined to implement concrete measures. As one informant commented, the provincial government tended to produce "high level statements but no execution"'.

Six interviewees complained about the uncertainty created by the three water-allocation and transfer system studies (the subject of the first case study above), given that there was an understanding that recommendations could result in altering water allocation in the region $^{8}$. The results of the three reviews took considerable time to complete, leaving critical questions of water allocation unanswered, frustrating those engaged in the CRP processes. Compounding this frustration was the fact that no changes to the allocation framework were ultimately forthcoming.

Other interviewees made negative statements specifically relating to the provincial department responsible for the environment. Three participants from watershed organizations were highly critical of the department in general, characterising its activity as obstructing rather than facilitating environmental management of resources ; and another two municipal councillors spoke of a general lack of direction from the department ${ }^{10}$.

An additional 12 comments related broadly to legislative and regulatory instruments, noting that there was either a lack of provincial regulation or that provincial regulation existed but was not being enforced. For instance, three interviewees spoke of the existence of provincial regulation to claw-back Calgary's unused license, but the province lacked the courage to do so because of Calgary's political clout ${ }^{11}$. In the absence of action taken by the province, they felt the city of Calgary was free to use their water license as a negotiating chip within the CRP process. One person stated:

It's the audacity to think you can take a license bigger than you need and profit from it while others are trying to get water from a river that has a moratorium. There's something wrong with that...but there's a lack of guts at the provincial level and they get a lot of MLAs (members of the provincial legislature) from Calgary so they're not likely to rock the boat ${ }^{12}$.

Several criticisms related to the water allocation system itself. One informant said the problem with water management in the province is a systemic one around a fundamentally flawed water allocation system which has no connection between the amount of water allocated in the sub-basin and the amount of water that flows through $\mathrm{it}^{13}$. Three interviewees said water should be managed as a provincial, not private, resource whereby water would be allocated according to need or uniformly across all populations in the Calgary region ${ }^{14}$. Statements included:

(Allocate water) based on some sort of need. Crops take this much, human nature just to stay alive takes this much. In other words lay out your list of needs and see how it goes ${ }^{15}$.

The government's responsibility is to manage that water in the interest of all Albertans not to manage that water in the interest of somebody who bought that license or somebody signed a piece of paper for a license in 1902 right $^{16}$ ? 
Based on interview data, there was a widespread view that if the development of a water management system within a regional framework was to succeed, greater provincial government involvement and clearer direction was needed. Given the long list of complaints enumerated by informants, one is led to believe the CRP and the water management plans within the process evolved within somewhat of a vacuum, leaving the CRP to its own devices.

\section{CONCLUSIONS}

In this study, two water management case studies were used to explore obstacles to improve water management in Alberta. The water allocation and transfer system explored in the first case study resulted in recommendations to leave the water allocation framework alone but to implement measures to improve the water transfer system. No recommendations, even relatively uncontroversial ones, have been implemented. An example of such a recommendation included a proposed three-tiered approval process, whereby transfers would be designated as low, medium or high in complexity and the degree of scrutiny of the approval process would increase accordingly. Based on the opinions of review participants, the obstacles preventing change are, perhaps not surprisingly, purely political and relate to: the degree of water constraints, the degree of public resistance, the importance of the issue relative to other problems on the government's agenda, the priorities of the Minister of the Environment, and the duration of his/her tenure in the portfolio.

Findings from the second case study provide support to the view that regional frameworks designed to manage land and water are highly complex and require government support to succeed. In this paper, the expectation of government support was explored in a case study of the CRP. This study presents consistent evidence in support of the call for greater government support and leadership across a range of measures. There is a need for the Alberta government to advance beyond strategic planning and broad frameworks, and to enact concrete measures, several of which were specified by participants. In the absence of such support and leadership, regional initiatives are left to their own devices. The study therefore confirms that measures taken at any one level will be partial, limited and possibly counterproductive if not located within a broader, supportive framework.

Although these case study results cannot be generalized to other cases, the findings have implications for solutions to water management. As water becomes increasingly scarce and therefore a more highly valued resource, the Alberta government will need to be more proactive in ushering in concrete water management measures. However, the complex, politically-imbued context within which water is managed in Alberta will likely become even more so as water scarcity (and thus, water value) increases. Government will therefore have to increase its resolve to provide the leadership required to make the necessary changes.

\section{NOTES}

${ }^{1}$ Interviewee \#5, employee of the Department of Environment.

${ }^{2}$ Interviewee \#1, member of a water-related organization.

${ }^{3}$ Interview \#21, member of a watershed organization.

${ }^{4}$ Interview \#14, councillor from Rocky View County.

${ }^{5}$ Interview \#4, town councillor from Turner Valley; interview \#5, town councillor from Airdrie; interview \#28, member of an ancillary water-related organization.

${ }^{6}$ Interview \#28, member of an ancillary water-related organization. 
${ }^{7}$ Interview \#27, anonymous member of an ancillary water-related organization.

${ }^{8}$ Interview \#14, councillor from Rocky View County.

${ }^{9}$ Interview \# 18, anonymous member of a watershed organization; interview \#19, anonymous member of a watershed organization; interview \#23, member of a watershed organization.

${ }^{10}$ Interview \#3, town councillor from Turner Valley; interview \#4, town councillor from Turner Valley.

${ }^{11}$ Interview \#10, councillor from Wheatland County; interview \#14, councillor from Rocky View County; interview \#28, member of an ancillary water-related organization.

${ }^{12}$ Interview \#13, councillor from Rocky View County.

${ }^{13}$ Interview \#27, anonymous member of an ancillary water-related organization.

${ }^{14}$ Interview \# 13, councillor from Rocky View County; interview \#20, member of a watershed organization; interview \#21, member of a watershed organization.

${ }^{15}$ Interview \#20, member of a watershed organization.

${ }^{16}$ Interview \#21, member of a watershed organization.

\section{REFERENCES}

[1] Johns, C., Introduction. In M. Sproule-Jones, C. Johns \& B. Heinmiller (eds). Canadian Water Politics - Conflicts and Institutions, McGill-Queen's University Press: Montreal, Canada, pp. 3-15, 2008.

[2] de Loe, R., Armitage, D., Plummer, R., Davidson, S. \& Moraru, L., From Government to Governance: A State-of-the-Art Review of Environmental Governance. Report prepared for Alberta Environment, Environmental Stewardship, Environmental Relations, Rob de Loe Consulting Services: Guelph, Ontario, 2009.

[3] Pollution Probe, A New Approach to Water Management in Canada, Vision and Strategy, 2008, Online. http://www.pollutionprobe.org/publications/a-new-approachto-water-management-in-canada-vision-strategy/. Accessed on: 10 Jan. 2014.

[4] Alberta Environment (AENV), Water for Life: Alberta's Strategy for Sustainability, Edmonton, Alberta, 2003. Publication \# I/955.

[5] Alberta Government, Alberta Economic Quick Facts, 2015, Online. https://albertacanada.com/files/albertacanada/SP-EH_AlbertaEconomicQuickFacts. pdf. Accessed on: 3 Mar. 2016.

[6] Alberta Environment (AENV), Draft Water Management Plan for the South Saskatchewan River Basin in Alberta, 2005, Online. http://www.assembly.ab.ca/lao/library/egovdocs/2005/alen/151901.pdf. Accessed on: 6 Feb. 2012.

[7] Nicol, L., Irrigation Water Markets in Southern Alberta, University of Lethbridge: Lethbridge, Alberta, Canada, 2005.

[8] Environmental Law Centre (ELC), Letter Re. Water for Life Strategy, 2007, Online. http://elc.ab.ca/Content_Files/Files/BriefsAndSubmissions/ELCCommentsonWaterF orLifeStategyRenewal.pdf. Accessed on: 6 Feb. 2014.

[9] Christensen, R. \& Droitsch, D., Fight to the Last Drop. A Glimpse into Alberta's Water Future. Prepared for Ecojustice and Bow Riverkeeper, 2008, Online. http://www.ecojustice.ca/wp-content/uploads/2014/11/Fight-to-the-Last-Drop-2008. pdf. Accessed on: 20 Feb. 2014.

[10] Bankes, N., Policy Proposals for Reviewing Alberta's Water (Re)Allocation System. Journal of Environmental Law and Practice, 20(2), pp. 81-126, 2010. 
[11] Roth, B.J. \& Howie, R.A., Land-Use planning and natural resource rights: The Alberta Land Stewardship Act. Journal of Energy and Natural Resources Law, 29(4), pp. 471-498, 2011.

[12] de Loe, R., Armitage, D., Plummer, R., Davidson, S. \& Moraru, L., From Government to Governance: A State-of-the-Art Review of Environmental Governance. Report prepared for Alberta Environment, Environmental Stewardship, Environmental Relations, Rob de Loe Consulting Services: Guelph, Ontario, 2009.

[13] Gibbs, D. \& Jonas, A., Governance and Regulation in Local Environment Policy: The Utility of a Regime Approach. Geoforum, (31), pp. 299-313, 2000.

[14] Jessop, R., Globalization and the National State: reflections on a Theme of Poulantzas. Rethinking the State. S. Aaronowitz \& P. Bratisis (Eds). University of Minnesota Press: Minneapolis, 1999.

[15] Gibbs, D. \& Jonas, A., Governance and Regulation in Local Environment Policy: The Utility of a Regime Approach. Geoforum, (31), pp. 299-313, 2000.

[16] Gibbs, D. \& Jonas, A., Rescaling and Regional Governance: the English Regional Development Agencies and the Environment. Environment and Planning C: Government and Policy, (19), pp. 269-288, 2001.

[17] Jessop, R., Capitalism and its Future: Remarks on Regulation, Government and Governance. Review of International Political Economy, 4(3), pp. 561-581, 1997.

[18] Norman, M., Regional Partnering for Global Competitiveness: The PlanningGovernance Challenge and the Calgary Regional Partnershi, University of Manitoba: Winnipeg, Manitoba, Canada, 2012.

[19] Pernitsky, D.J. \& Guy, N.D., Closing the South Saskatchewan River Basin to new water licenses: Effects on municipal water supplies. Canadian Water Resources Journal, 35(1), pp. 79-92, 2010.

[20] CH2M Hill., CRP Regional Servicing Study: Short- and Long-Term Servicing Challenges. Technical Memorandum 4.1., 2007, Online. http://journals.brandonu.ca/ jrcd/article/download/1220/292. Accessed on: 22 Oct. 2011.

[21] Nicol, L., Water and City-regionalism: Discourse, Power and Hidden Dynamics, University of Lethbridge: Lethbridge, Alberta, Canada, 2013.

[22] Water Matters., Understanding Alberta's Emerging 'Water Market', 2008, Online. http://www.water-matters.org/node/219. Accessed on: 22 Feb. 2014. 